\title{
Religious Practices On Honoring The Dead: Need For Contextualized Christian Formation
}

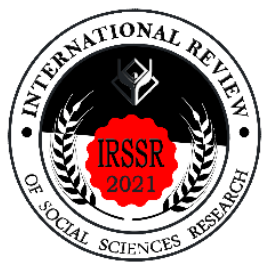

\author{
Julio Ramillo A. Mercurio
}

\begin{abstract}
Filipinos' deep respect for the dead impelled the culture of holding wake, interment and memorial as expression of reverence and tribute. Although Filipinos' daily life are influenced by Catholic teachings, there is an observable lack of knowledge of and formation in the faith. This article investigated on the rich, yet often neglected, literature that surrounds Christian formation and religious practices on honoring the dead in the Philippines. Understood as a heritage in itself, there is a need to preserve, protect, and promote such social practice on honoring the dead. Despite the call of the particular Church in the Philippines towards a renewed catechesis on Christian life, death and afterlife, there have been no available learning module or program for families of the departed that has been created, nor implemented. This study argued that by integrating a contextualized learning resource in the existing learning package for Religious Education, crafting of lessons which are responsive to the educational and social context of learners - specifically on topics that touches Catholic doctrines on life, death and afterlife - will aim at a deeper appreciation of Catholic doctrines, leading to authentic witnessing to the Faith through one's own cultural identity.
\end{abstract}

Keywords:

Christian formation, honoring the dead, contextualized learning resource, Religious Education, religious practices

Suggested Citation: Mercurio, J.A. (2021). Religious Practices on Honoring the Dead: Need for Contextualized Christian Formation. International Review of Social Sciences Research, Volume 1, Issue 1, pp. 77 - 95.

\section{About the author:}

Research Director, Maryhill College, Inc., Lucena City, Philippines and PhD Student, Southern Luzon State University, Lucban, Quezon, Philippines. 


\section{Introduction}

The concept of death in itself is bittersweet. Although known to all that death is inevitable, it is always a taboo in most culture to talk about the concept - "death" - in casual, everyday manner. Yet, ironic as it is, there is that strong devotion and respect to the dead, and to the very concept of death. History proves that people of ancient times would even form cults around death and personifications of death. The likes of Egypt's Anubis and Osiris, Greece's Hades, and Mexico's La Santa Muerte are just some of the concrete examples of Man's natural wonder on the reality of death and the life thereafter.

This reverence to the dead is visibly manifested in Filipino culture. Even before the Spanish colonization, early Filipinos believe in the concept of life after death (Tope \& Nonan-Mercado, 2002). This belief in an afterlife prompted the Filipinos to construct customs and beliefs on burial to somehow honor the departed through sense-evoking rituals. The most prominent practice is by holding a wake as way for the loved ones to properly mourn the death of one who is dear to them (Hays, 2008).

Due to Catholicism, majority of Filipinos adhere to Catholic teachings concerning death. The Catholic Church teaches that death is the end of earthly life, and the beginning of "that" life with God. That aspect of death leads urgency to one's life: remembering that "mortality" helps one realize that one only has a limited time in which to bring one's life to fulfillment (Catechism of the Catholic Church 1993, para. 1007).

However, despite the great Catholic influence on the daily life of Filipinos, there is a great lack of knowledge of and formation in the faith (Second Plenary Council of the Philippines 1991, para. 13). It is the hope of the Second Synod of the Diocese of Lucena that a renewed catechesis be promoted in the holistic formation of the individual person in every facet of life (Second Synod of the Diocese of Lucena, 2004). Yet, no catechetical module or program for families of the departed has been created, nor implemented, since the end of the Second Synod. It has been observed, more so, that instructors of Religious Education lack essential resources in the teaching of sacraments and sacramentals - wherein lessons on Catholic teachings about life, death and the afterlife are essentially part of.

Understood as a heritage in itself, there is a need to preserve, protect, and promote such social practice on honoring the dead. UNESCO (2015) reiterates that in the midst of rapid globalization, the transmission and constant "re-creation" of relevant practices, 
cultures, traditions, and the like, ensures viability of intangible cultural heritage and provides a sense of identity, continuity, and respect for cultural diversity and human creativity. UNESCO points out further that formal education plays a key role in safeguarding intangible cultural heritage. Correlatively, the 1987 Constitution of the Philippines mandates the conservation, promotion and popularization of nation's historical and cultural heritage and resources (1987 Constitution of the Philippines, Article XIV, sec. 15).

Catholic schools are not exempted from this mandate. In fact, it is through the Catholic schools that the Church participates in the dialogue of culture with her own positive contribution to the cause of the total formation of man (Gravissimum Educationis 1965, para. 15). And with the advent of a new curriculum for basic education in the Philippines, mandated by Republic Act 10533 or the "Enhanced Basic Education Act of 2013," there is a strong need for religious educators to incorporate contextualized lessons in their teaching program in order for the learners to better and deeply appreciate the Church teachings, which at present seems ambiguous, detached and separated from their daily life (Mercurio, 2016).

The 2012 Synod of Bishops on New Evangelization challenges Catholic educational institutions to become "agents of evangelization, and not just products of evangelization." Religious Education, then, should be concerned not only with intellectual formation, but also with emotional and affective learning - with a specific mission towards a critical, systematic transmission of culture in the light of faith, and the bringing forth of the power of Christian virtue by the integration of culture with faith, and of faith with living (Congregation for Catholic Education, 1997). Hence, the learning experience in religious education should be rooted on the respective educational and social contexts or learners, and on the common and shared experience of learners themselves, that is responsive to the needs of the times.

By looking into the available literature on religious practices on honoring the dead, as well as Christian formation on life, death and afterlife, one will be able to create possibilities of conserving a modus vivendi, which can rightly be called a heritage in its own right. Under the same perspective, the teachings of the Church on life, death and afterlife will be better appreciated. Learners will become aware that reverence for the dead - and the hope for the life thereafter - is not simply an ambiguous doctrine passed on by the Church to Her sons and daughters. Rather, it is a unique lived experience which cannot be detached from Man's 
reality (Lumen Fidei 2013, para. 38). This study wishes to address the challenge of [trans] forming authentic living witnesses to the Faith through one's own cultural identity.

\section{Methodology}

This research made use of narrative review approach in examining available literature on the Christian doctrine on life, death and the life, as well as religious practices on honoring the dead. Snyder (2019) beautifully explained that a narrative review (or semi-systematic review) approach to literature and studies is appropriate to be used when topics have been conceptualized and studied by various groups of researchers within diverse disciplines and in varied lenses.

Various literature that focus on different areas, like: philosophy, death studies, religious education, instructional materials development, and theology among others were subscribed to by the author to arrive at a comprehensive and systematic review of available and up-to-date literature.

Literature exhausted in this article will shed light on religious practices on honoring the dead in the Philippine context, effect of religious practices on honoring the dead to Christian formation, and Christian formation and religious education.

\section{Results and Discussion}

At the outset, many researchers have asserted that not much scholarly attention has been given to the concept of death and its outliers, like: grief and mourning, funerals and the like (see Sharp, J. G., Bowker, R., \& Byrne, J., 2008; Kastenbaum, R., 2000; Richardson, R., 2000). Such is because the concepts mentioned are taboo in everyday conversation.

\subsection{Phenomenological argument on death}

Death is a mirror of life. One cannot talk about death, without talking about life. When one expounds on the concept of "dying," one cannot but expound on the very nature of mortality - one died because such one lived.

In its face value, death may be seen as a biological event, a natural scientific reduction. As Heinämaa (2015) would argue, death, as a biological event, is something mute and decomposable. In the natural scientific reduction, death is seen as a natural end of one's 
biological or organic life - similar to the perishing of animals and the wilting and withering of plants, and comparable to the breakdown of machines, such as the 'dying' of an engine. In such reflections, death is "given" to a person as one natural occurrence among other natural occurrences.

On the other hand, the common understanding of death as a concept is deeply anchored towards "the other." As Peach (2000) describes, death is "a 'case' that happens to others." Children, for example, usually start asking questions about death and mortality when exposed to dead animals; and in adult life, the death of a parent or an immediate family member is often an awakening and disenchanting experience. From here we can see that the phenomenological argument is focused not about the way in which we come to realize a possibility, but about the meaning of this possibility - not on how one comes to realize that one dies, but on the meaning of death itself. Moreover, the argument is not whether one's own death or life is more important or more significant to the person inquiring than someone else's death or life; rather, one can only understand the meaning of death by facing the possibility of one's own death, and by studying what implications this "impossible possibility" has to one's life here and now.

Walter (2008) attested that death is an institutionalized phenomenon. It is the "nucleus of a particular 'culture complex' involving interrelated cultural traits working together in a more or less consistent and meaningful way." In this manner, death brings people together. "When someone dies, the group to which he belongs feels itself lessened and, to react against this loss, it assembles" (Durkheim, 1915, cited in Walter, 2008). Thus, independent of religion, location, ethnicity or time epoch, death is the unique inevitable reality that unites all humanity and every other created being. It correlatively involves culturally-defined and socially-characterized meaning of death, mourning, ceremonies, rites and practices relative to death and dying, and the impact of attitudes towards death upon one's personal and social life.

From a philosophical perspective, the German philosopher Edmund Husserl (ca. 1859-1938) argued that one's understanding of death and/or mortality brings about cultural objectivity - i.e., a sense of culture. According to him, in order to understand the special character of cultural objectivity, one must distinguish between conscious and self-conscious subjects: on the one hand, subjects who are conscious of themselves as mortal beings and, on 
the other hand, subjects who lack consciousness of themselves as mortals. Husserl argues that only subjects who are conscious of their own finitude, mortality and natality, are those that can consciously relate to non-contemporary others, and thus participate in activities and practices that involve asynchronous subjects in an open infinity of generative becoming. Thus, more than a biological event, death is more of a transit - a rite of passage - a "yet-tocome."

\subsection{Religious practices on honoring the dead.}

Before the spread of Catholicism in the Philippines, early "Filipino" settlers pay great respect to the dead (Schumacher, 1987). This is because it is the belief of early Filipinos that when one dies, one becomes an anito serving Bathala (God). As anitos, they become an intercessor of the living to the Divine Provider. Death, for the early Filipinos, is not the end; rather, a beginning of a new way of living. This is evident in the Filipino saying, "Kapiling na siya ng Maykapal."

In retrospect, Filipinos have long been practicing respect for the departed even before the Spanish colonization. Dakudao (1992) reports in his article, entitled: "The Development of Cemeteries in Manila Before 1941," the Pre-Christian Filipinos observe honor to the dead by offering not only material pabaon (provision for the "trip" to the afterlife) like food, beverage, clothings, and the like, but also spiritual pabaon or prayers for the dead. (In Dakudao's article, it was mentioned as “obsequy" or the last office for the dead).

Citing the work of the Spanish Jesuit historian, Pedro Chirino, in J.N. Schumacher's "Readings in Philippine Church History" (1983), Dakudao (1992) continues to report that There are five ways on how early Filipinos honor the dead and perpetuate their memory by immortalizing their remains: (1) boat-coffins (usually found on coastal or near-coastal areas within the Philippine archipelago, (2) jars (usually found in areas near caves, similar to the Manunggul jars found in Palawan), (3) simple inhumation, (4) cremation, and (5) in-house burial (or burial within their domicile). Respect to the departed loved one is evident from the preparation for the body for burial (using flowers and other aromatics) to the burial itself (which may include garments, jewelries, china wares, coins, and the like. Heinlein (2017), on the other hand, gives a logical explanation on the use of flowers during funeral. According to 
him, flowers represent the transitory life of man that highlights the true fact of life's eternity and immortality.

As an archipelagic nation, these "religio-cultural" practices on honoring the dead by early Filipino settlers, developed an encompassing range of regional variations, which resulted as a product of the enculturation between folk religiosity and Catholic teachings and practices. Deeply rooted on that hope for the afterlife, The Funeral Source (2014) from Cincinnati, Ohio, highlighted some customs and traditions of paying homage to departed loved ones across the Philippine archipelago:

a) In Benguet, Mountain Province, the departed loved one is blindfolded, and then seated on a chair near the house's main entrance. The arms and legs are secured using a tie. A bangil rite, or a chanted narration of the dead's lifetime.

b) Some rural customs in Cavite makes use of trees as burial places. When a person is seen to be dying soon, a simple hut is erected close to the tree that the dying person has chosen. And when that person dies, they are vertically entombed inside the hollowed-out tree.

c) In the Ilocos regions, pompon (or burial rites) are performed by the wife of a dead husband. It is only the wife who prepares the cadaver by clothing it with "waking clothes." When a woman dies, on the other hand, she is clothed with a black motif. The head is shrouded with a black handkerchief (manta).

d) The B'laan tribe of Mindanao wrap their dead inside barks of trees, and the body is suspended from treetops.

The abovementioned Filipino customs and folk traditions only validates that benevolence the Filipino - as a people, although separated by bodies of water - accord the departed.

In a contemporary Filipino setting, wakes, or viewings, are an opportunity for family and friends to come together, console each other and recall the impact the deceased had on them. Villafuerte and de Guzman (2019) noted that as a gesture of gratitude, snacks are offered to those who attend the wake. As a matter of fact, the bereaved family stops all personal business. Furthermore, rather than working or continuing typical exercises, the family cooks and makes different arrangements for the appearance that is continuous until the burial. 
Aside from prayers and vigils, which are of primordial importance, sending of flowers or mass cards are sincere gestures of sympathy and consolation. In olden times, flowers were placed on and around the casket of the deceased to perfume the area and ward off the smell of the decaying body (Roman Catholic Diocese of Davenport, 2013). In today's time, flowers are used as decoration to signify peace and rest. The Order of Christian Funerals (1989, para. 38) recommends the use of flowers and other Christian symbols in funeral liturgy as it enhances the funeral setting.

A peculiar note on the culture of Filipinos during interment was highlighted by Hays (2008). He observed that coffins are carried out of the funeral chapels with feet side first, and is placed at church facing the sanctuary. When the elder members of the family or the community were asked why such is practiced, they replied that it symbolizes the exit of a normal, living person, and is likened to a normal, living person attending Church services.

The observation made by Hays (2008) would predict consequently that the deceased is placed facing the sanctuary to liken to a normal living person attending Church services. This tradition, handed down from one generation to another, is an evidence of the respect that the Filipino people accord the deceased.

Honoring of the dead in Filipino culture does not only end in the burial. Rather, it extends for a lifetime. The National Center for Culture and the Arts (2015) notes that Filipino Catholics would hold pa-siyam in the belief that it is only on the ninth (9th) day after a person has died can s/he pass on to the next life. It is also part of the Filipino mourning tradition to commemorate babang luksa or the first anniversary of death. As the name suggests, it ends the mourning period of the bereaved family. Aside from visiting the grave of the departed loved ones, prayers and Masses are also offered. Meals are served as gestures of gratitude to those have joined the celebration.

\subsection{Religious practices on honoring the dead and Christian formation}

Understanding death as a "transit" rather as an "end" is evident in the Catholic Church teachings. Christ's Paschal Mystery - Passion, Death and Resurrection - is the hinge that interconnects the concepts of death and afterlife in Catholic teachings. The Catholic teachings on life, death, and afterlife responds to the fundamental human question: "What can we hope for?" As Jesus Himself has died and risen, so we, too, who believes in him, shall 
die and shall rise. The Sacred Scriptures has this to say: “... I am the resurrection and the life. Those who believe in me, even though they die, will live, and everyone who lives and believes in me will never die." (Jn. 11:25, NRSV). As our faith in Jesus Resurrected ensures our citizenship in heaven, it is from there that one eagerly awaits the coming of our Savior, the Lord Jesus Christ. By affirming the resurrection of the body and life everlasting (CCC 1993, para. 988ff and 1021ff), it completes a believer's journey from faith to love to hope the three greatest Christian virtues extolled by St. Paul (1 Cor. 13:13) that activate our Christian living. These three greatest Christian virtues are called "theological" virtues because "they arise from God's free gift and are directed immediately toward God, infinitely trustworthy and lovable" (CFC 1997, para. 2022). Hence, one can say that without "the resurrection of the dead," the whole structure of Christian faith collapses. Without "life everlasting," the Gospel promises and meaning of creation and redemption disappear, and earthly existence loses its "faith in what is hoped for, and conviction about things we do not see" (Heb. 11:1).

This act of "hoping" is firmly grounded on the Catholic teaching about "eschatology." Eschatology is a part of systematic theology which deals with the doctrines of "the last things" (ta eschata). The primary biblical basis for eschatology is centered more on humankind's collective destiny expressed in the Old Testament messianic hopes, and directly grounded in Jesus Christ in the New Testament (CFC 1997, para. 2029).

Moreover, it is from this act of "hoping" that Catholic practices on honoring the dead is very evident on three events: wake, interment and memorial. The Order of Christian Funerals (1989) stresses the ministry of the Church and of the Christian community in accompanying mourners in their moment of grief. Centered on the word of God as the source of consolation, prayers and the vigil rites are intended for the mourners to "express their sorrow and to find strength and consolation" in the paschal mystery of Christ (OCF 1989, para. 51-52, 56, 59-60).

Aside from prayers and vigils, which are of primordial importance, sending of flowers or mass cards are sincere gestures of sympathy and consolation. In olden times, flowers were placed on and around the casket of the deceased to perfume the area and ward off the smell of the decaying body (Roman Catholic Diocese of Davenport, 2013). In today's time, flowers are used as decoration to signify peace and rest. The Order of Christian 
Funerals (1989, para. 38) recommends the use of flowers and other Christian symbols in funeral liturgy as it enhances the funeral setting.

The meaning of death was transformed from a curse to a blessing by Jesus' willful obedience to the will of the Father. Despite his anguish as he faced death, he accepted it in an act of complete and free submission to the will of the Father (cf. Mk 14:33-34; Heb. 5:7-8). Because of this magnanimous example of Christ Himself, Christian death is now given a positive meaning. The Catechism of the Catholic Church (1993, para. 1010) presents that through the Sacrament of Baptism, the Christian has already "died with Christ" sacramentally, in order to live a new life; and if we die in Christ's grace, physical death complete this "dying with Christ," and so completes our being one with Him in His redeeming act.

For these reasons, the highlight of honoring the dead should be about Christ - as encountered or revealed in the life of "this faithful Christian that has died, of this community that mourns him or her." Catholic believers should not celebrate the life of the deceased in and of themselves or speak in remembrance of them in an exaggerated way, but recall their lives as a sign of God's grace and generosity, of God's presence and action in the world. Liturgy is not celebrated as an exercise in isolated self-expression, but only as an expression of the faith of the Church (Roman Catholic Diocese of Davenport, 2013).

During interment, liturgical actions also point out to our hope for union with Christ. The Funeral Liturgy is closely tied with the Rites of Baptism (OCF 1989, para. 4). The sprinkling of the holy water to the deceased is a gentle reminder to those living present of the baptismal promises made by the deceased when s/he was still living, and the promise of eternal life in Christ given to those who believe. More so, the ritual symbols of water, the paschal candle, the pall, the proclamation of the Word of God and the journey to the altar, all recall the journey that begins in baptism (St. John Vianney Catholic Church - Archdiocese of Galveston-Houston, 2010).

It has to be clarified also that the Holy Eucharist should be the center of this hopeful celebration, as it is "the source and summit of the Christian life" (LG 1964, para. 11). All other sacraments, and all ecclesiastical ministries and works of the apostolate, are bound up with the Eucharist and are oriented toward it (CCC 1993, para. 1324). At the death of a Christian, the Church intercedes on behalf of the deceased because of its confident belief that 
death is not the end (OCF1989, para. 4). Christians celebrate the funeral rites to offer worship, praise, and thanksgiving to God for the gift of a life which has now been returned to God, the author of life and the hope of the just. The Mass, the memorial of Christ's death and resurrection, is the principal celebration of the Christian funeral (OCF 1989, para. 5).

For those who grieve one's passing, life before this death has ended; life after this death is yet to start. The day-in and day-out routine have to be learned and accepted without the dear departed being physically present. The Rite of Committal serves as the starting point of that life without the departed, with new identities as widow(er) instead of spouse, orphan instead of child. Likewise, the deceased is also incorporated into the community in a new way: in memory, and as part of the Church outside of time (Roman Catholic Diocese of Davenport, 2013).

Since death is understood as the end of Man's earthly pilgrimage, "it is appointed that man should only die once." (Heb. 9:27). It is very clear in the teaching of the Catholic Church that there is no reincarnation (CCC 1993, para. 1013). Because of this premise, the Church urges the faithful to prepare themselves for the hour of death: to ask God to deliver him from sudden and unforeseen death, to ask the Blessed Virgin to intercede for him "at the hour of death," and to entrust himself to St. Joseph, the patron of happy death (CCC 1993, para. 1014).

On the other hand, the dying should also be given due attention and care to help them in living their last moments in dignity and peace. Prayer is of primordial importance. Immediate family members and relatives should make sure that the sick receive the sacraments (i.e., Reconciliation, Holy Eucharist and Anointing of the Sick) at the proper time, preparing them to meet the living God (CCC 1993, para. 2299).

More so, the bodies of the dead must be treated with respect and charity, in hope of the Resurrection. The burial of the dead is at the forefront of Catholic practice. It is a corporal work of mercy (CCC 1993, para. 2447) that honors the children of God, who are temples of the Holy Spirit. It is wise to note that the Church allows cremation, provided that choosing cremation over burial is not a demonstration of a denial of faith in the resurrection of the body (cf. can. 1176 §3). The recent instruction, "Ad resurgendum cum Christo," published by the Congregation for the Doctrine of Faith (2016), underscores the provisions 
regarding the burial of the departed and the conservation of the ashes in the case of cremation.

\subsection{Christian Formation and Religious Education}

Since the Church has the responsibility of announcing the way of salvation to all men, of communicating the life of Christ to those who believe, and of assisting men to be able to come to the fullness of this life (GE 1965, para. 3), She [the Church] is bound, as a mother to give to these children of hers, an education by which their whole life can be filled with the spirit of Christ, and at the same time do all she can to promote for all peoples the complete perfection of the human person, the good of earthly society and the building of a world that is more human. And there can be no other best avenue for this but the School (in our context, "Catholic School”).

Among all educational mechanisms, the school is of special importance (GE 1965, para. 5). It is designed not only to develop with special care the intellectual faculties, but also to form the ability to judge rightly, to hand on the cultural legacy of previous generations, to foster a sense of values, and to prepare for professional life. Between learners of different talents and backgrounds, it advances cordial relations and cultivates a feeling of common comprehension; and it sets up, in a manner of speaking, "a middle ground" whose work and progress must be shared together by families, educators, relationship of different kinds that encourage social, urban, and strict life, just as by common society and the whole human network.

By attaching the qualifier "religious" (or in another context, "Christian") in education, it would infer that such educative process is centered on religion (or in a more secular tone, "a belief in the Divine"). From here, the Catholic Church, through its Declaration on Christian Education (1965), goes even further to define that: A Christian education does not merely strive for the maturing of a human person ... but has as its

principal purpose this goal: that the baptized, (1) while they are gradually introduced the knowledge of the mystery of salvation, (2) become ever more aware of the gift of Faith they have received, and that (3) they learn how to worship God the Father in spirit and truth (cf. John 4:23) especially in liturgical action, and (4) be conformed in their personal lives according to the new man created in justice and holiness of truth (Eph. 4:22-24); also that (5) 
they develop into perfect manhood, to the mature measure of the fullness of Christ (cf. Eph. 4:13) and (6) strive for the growth of the Mystical Body; moreover, that aware of their calling, (7) they learn not only how to bear witness to the hope that is in them (cf. Peter 3:15) but also how to help in the Christian formation of the world that takes place when natural powers viewed in the full consideration of man redeemed by Christ contribute to the good of the whole society.

With Religious Education as the "core" of Catholic School curriculum (CEAP, 2014), Catholic Schools provide a stable and systematic evangelization within the context of the local church (CBCP, 2012). The influence of the Church in the field of education is shown in a special manner by the Catholic school, which is focused and directed to pursue cultural goals and the human formation of youth. Gravissimum Educationis beautifully explains:

"The proper "function" of a Catholic School is (1) to create for the school community a special atmosphere animated by the Gospel spirit of freedom and charity, (2) to help youth grow according to the new creatures they were made through baptism as they develop their own personalities, and finally (3) to order the whole of human culture to the news of salvation so that the knowledge the students gradually acquire of the world, life and man is illumined by faith. So indeed, the Catholic school, while it is open, as it must be, to the situation of the contemporary world, leads its students to promote efficaciously the good of the earthly city and also prepares them for service in the spread of the Kingdom of God, so that by leading an exemplary apostolic life they become, as it were, a saving leaven in the human community." (GE 1965, para. 8).

The Catholic school can be such a guide to the satisfaction of the strategic the People of God and to the encouraging of the discourse between the Church and humankind, to the advantage of both. Thus, we can conclude that Catholic education is cultural and at the same time transformative.

The integration of subjects and areas of learning in educational projects or themes helps pupils to understand the relationships that exist between seemingly disparate topics. Components of cultural education can be combined with numeracy and literacy, sport, science, technology, world studies, history, geography and many other subjects. A project 
which focuses on pupils' local community, for instance, can encompass architectural design and spatial planning, the rhythm and pattern of the streets, social interaction in the area, the calculations that underlie perspective and proportions, and the history that has shaped the neighborhood. Cultural education also makes an important contribution to the overall development, citizenship and identity of pupils by making them aware of their own cultural background and enabling them to contribute to its further development. Thus, in order to create an instructional material that is localized, contextualized, culture-related, as well as responsive to the respective educational and social contexts of students, the experiences of individuals and communities concerned have to be synthesized.

In this note, the Second Plenary Council of the Philippines (1992) seeks for a holistic transformation of the total person through renewed evangelization (see Part III of PCP II). PCP II had clearly pointed out that that a big percentage of Filipinos do not receive adequate catechesis (PCP II 1992, para. 156 and 183). The Second Synod of the Diocese of Lucena (2004), in its document on "Integral Evangelical Formation towards Proclamation and Evangelization" (para. 16), benevolently recommends a catechesis intended for the Anointing of the Sick, and for the families of the departed, "to accompany them in their time of grief, and to strengthen their hope in the eternal life" (see para. 30).

\subsection{The need for a learning resource in Christian Formation}

Religious education is a great vehicle cultural transmission and belief in the Divine. As education should not be viewed in a limited manner as exclusively cognitive and individualistic, Wardekker \& Miedema's (2001) defines that learning is a "growing capacity or the growing competency of pupils to participate in culturally structured practices." The idea of participation is fundamental here. It is not restricted to actual participation in face-toface communication processes. Rather, all individual activities are seen as components or parts of an including arrangement of social practices, and people are seen as taking an interest in social practices in any event, when they act in physical segregation from others. All individual activities are seen as components or parts of an including the arrangement of social practices, and people are seen as taking an interest in social practices in any event, when they act in physical segregation from others. In other words, being able to show that you 'know' the subject-matter is not the main criterion for a successful learning process, it is 
only the starting point for 'real' learning processes in which both the subject-matter and the learner are transformed. This transformation by definition takes place in a social context or setting. Such a context is not to be interpreted as limiting, but as constitutive for all socially and culturally situated and structured acting and actions. Thus, we can formulate the aim of the school as enabling pupils to participate in socially and culturally structured practices that take place at a certain time and that are located within a particular societal setting.

In order for the transmission of culture, tradition and belief be realized to its optimum, a localized and context-based instructional material must be produced, introduced and evaluated. By using real-world context learning outcomes can be enhanced since social relationships, tools, and engaged experiences, can make the best learning environments. Together with other socio-cultural learning theorists, they are convinced that learning isn't something that occurs in seclusion, or is simply inside the head, yet is molded by the unique circumstance, culture, and apparatuses in the learning circumstance.

Together with this, a learning resource made available for teachers and students can be a big help in defining the characteristic of one's self in relation to his/ her social groups. As textbooks are among the most commonly-used student materials in a learning classroom, student texts and their accompanying teaching guides are widely-used resource in selecting activities and learning content.

Within the context of religious education, learning resources can help teachers, both budding and seasoned, handling Christian Living subjects, address issues related to religious education, including availability of resources and content knowledge, despite lack of necessary academic qualifications and experience in teaching religion and doctrine-related lessons (Rymarz \& Engebretson, 2005). However, in the same context, there is a growing number of deficiencies in terms of qualified and experienced teachers (Chater \& Erricker, 2013). Not discounting the capacity of present lay teachers teaching Christian Living in the Philippines, a contextualized learning resource as another option to the already existing learning package that teachers utilize will be able to address issues concerning poor teaching methodology and lack of available resources (Gearon, 2013). Up-to-date teacher training in forms of seminars/ workshops is also necessary to capacitate and re-tool teachers. Thus, in effect, availability of learning resources will be beneficial to achieve better the objectives of 
the lessons and the very purpose, not only of catechesis, but most especially of religious education.

Learning Resources, as defined by UNESCO International Bureau of Education (2015), are "any resource - including print and non-print materials and online/open-access resources - which supports and enhances, directly or indirectly, learning and teaching." They are either texts, videos, softwares, hardwares, or other similar education materials that teachers utilize in order to assist students in meeting learning expectations defined in the curriculum (Saryati and Yulia, 2019). Hence, careful selections of learning contents are crucial to the success of student achievement. Instructional materials can bolster student learning and enhance student success. Ideally, instructional materials should be tailored to the context in which they will be used. It should be grounded on learning goals, assessments of student understanding, as well as effective and engaging activities (Wiggins \& McTighe, 2005). It may also include guided demonstration, return demonstration, and feedback from the learners. Through a carefully scaffolded problem sets and well-sequenced instructions and demonstrations, learning resources can aid teachers are to pinpoint precisely where a learner is struggling, and provide an avenue for teachers to respond most favorably.

Within Religious Education setting, readily accessible contextualized learning resources can likewise be a means to help an educator in giving a progressively solid witness to the model of an individual that should be believed and imitated. The Congregation on Catholic Education (1982) admonishes that by contextualizing lessons, students will be able to see concepts within the teachings of the Catholic Church as "something reasonable and worthy of being lived, something concrete and realizable" (Lay Catholics in School, para. 32).

As a reference, learning resources can help teachers identify what values are embodied in the textbook and relate these values to teachers' opinions about the educative process of teaching and learning.

\section{Conclusion}

The Filipino culture is rich in its ways of honoring and respecting the departed members of the community. This is visibly manifested in the manner they hold wake, interment and memorial. Contemporary traditions on honoring the dead are heavily grounded on Catholic teachings on life, death and the afterlife - the doctrine being a transit from "here" to the 
"thereafter." Despite the lack of available learning materials integrated in the Religious Education courses in Catholic schools, the need to integrate appreciation of these "religiocultural" practices is necessary in order to create an educational community that is animated by Gospel values.

\section{References}

Baring R., Cacho R.G. (2015) Contemporary Engagements and Challenges for Catholic Religious Education in South East Asia. In: Buchanan M., Gellel AM. (eds) Global Perspectives on Catholic Religious Education in Schools. Springer, Cham.

Baring, R. (2010). A new approach to catechesis: involving students in catechetical education in the Philippines. International Studies in Catholic Education, 2(2), 176-192. doi:10.1080/19422539.2010.504027

Baring, R. (2011). Plurality in Unity: Challenges Toward Religious Education in the Philippines, Religious Education, 106(5), 459-475. doi: 10.1080/00344087.2011.613342

Catholic Bishops' Conference of the Philippines. (1992). Acts and Decrees of the Second Plenary Council of the Philippines. Pasay City: Paulines Publishing House.

Catholic Bishops' Conference of the Philippines. (1997). Catechism for Filipino Catholics. Manila: Word and Life Publications.

Catholic Bishops' Conference of the Philippines. (2012, January 29). Pastoral Letter on 400 years of Catholic Education in the Philippines. Retrieved 01 March 2019, from https://www.ceap.org.ph/upload/download/20127/30164744114_1.pdf

Catechism of the Catholic Church. (1994). Vatican City: Libreria Editrice Vaticana.

Chater, M., \& Erricker, C. (2013). Does religious education have a future?: pedagogical and policy prospects. Milton Park, Abingdon, Oxon: Routledge.

Congregation for Catholic Education (1982). Lay Catholics in schools: witnesses to faith. $\begin{array}{llll}\text { Retrieved } & 21 & \text { March } & \text { 2019, from }\end{array}$ https://www.vatican.va/roman_curia/congregations/ccatheduc/documents/rc_con_ccathed uc_doc_19821015_lay-catholics_en.html

Dakudao, M. (1992). THE DEVELOPMENT OF CEMETERIES IN MANILA BEFORE 1941. Philippine Quarterly of Culture and Society, 20(2/3), 133-150. Retrieved March 5, 2021, from http://www.jstor.org/stable/29792084

Francis (2013). Lumen fidei: Encyclical letter of the Supreme Pontiff Francis to the bishops, priests, and deacons, consecrated persons, and the lay faithful on faith. New York, NY: Image.

Gearon, L. (2013). Masterclass in religious education: transforming teaching and learning. London: Bloomsbury. 
Hays, J. (2008, June). Funerals in the Philippines. Retrieved 03 March 2019 from http://factsanddetails.com/southeast-asia/Philippines/sub5_6c/entry-3864.html

Heinämaa, S. (2010). Being towards death. In R. Schott (ed.) Death, Birth and the Feminine. Bloomington: Indiana University Press, 98-155.

Heinämaa, S. (2015). The Many Senses of Death: Phenomenological Insights into Human Mortality. Collegium 19(1), 100-117.

Heinlein, M.F. (2017 May). Planning and Understanding the Catholic Funeral. OSV Newsweekly. $\quad$ Retrieved March 2019, from https://www.osvnews.com/2017/05/07/planning-and-understanding-the-catholic-funeral/

Kastenbaum, R. (Ed.). (2000). The psychology of death. Springer Publishing Company.

Laguilles-Villafuerte, S., \& de Guzman, A. B. (2019). Aging Filipino siblings' interment preferences: application of conjoint analysis. Educational Gerontology, 45(9), 559-572. doi.org/10.1080/03601277.2019.1676501

Mercurio, J. A.. (2016). YHWH and "His" Exclusive Cult: Israel in Deuteronomy. Tilamsik, 8(2). Retrieved from http://ejournals.ph/form/cite.php?id=9988

National Commission for Culture and the Arts. (n.d.). Philippine Cultural Education Program (PCEP). Retrieved 29 March 2019, from https://ncca.gov.ph/philippinecultural-education-program-pcep/

National Conference of Catholic Bishops (1989). Order of Christian Funerals. Totowa, NJ: Catholic Books Publishing, Co.

New Revised Standard Version. (1999). Oxford: Oxford University Press.

Paul VI (1965). Declaration on Christian Education (Gravissimum Educationis). Retrieved 13 March 2019 from http://www.vatican.va/archive/hist_councils/ii_vatican_council/documents/vatii_decl_19651028_gravissimum-educationis_en.html

Peach, F. (2000 July). Death, Faith and Exitentialism. Philosophy Now, issue 27. Retrieved 21 March 2019 from https://philosophynow.org/issues/27

Richard Rymarz \& Kath Engebretson (2005) Putting textbooks to work: empowering religious education teachers. British Journal of Religious Education, 27:1, 53-63, doi: $\underline{\mathbf{1 0 . 1 0 8 0 / 0 1 4 1 6 2 0 0 5 2 0 0 0 2 7 6 5 2 8}}$

Richardson, R. (2000). Death, dissection and the destitute. Chicago, IL: University of Chicago Press.

Roman Catholic Diocese of Lucena (2004). Acts of the Second Synod of Lucena. Lucena City: Imprenta Lucentina. 
Rymarz, R., \& Engebretson, K. (2005). Putting textbooks to work: empowering religious education teachers. British Journal of Religious Education, 27(1), 53-63. doi:10.1080/0141620052000276528

Saryati, T., \& Yulia, Y. (2019). Contextual teaching and learning approach to supplementary reading materials based on 2013 Curriculum. Journal of English Language and Pedagogy, 2(1), 1-7. doi:http://dx.doi.org/10.36597/jelp.v2i1.3703.

Schumacher, J. N. (1987). Readings in Philippine church history. Quezon City: Ateneo de Manila University, Loyola School of Theology.

Sharp, J. G., Bowker, R., \& Byrne, J. (2008). VAK or VAK-uous? Towards the trivialisation of learning and the death of scholarship. Research Papers in Education, 23(3), 293-314. doi.org/10.1080/02671520701755416

THE 1987 CONSTITUTION OF THE REPUBLIC OF THE PHILIPPINES - ARTICLE XIV | Official Gazette of the Republic of the Philippines. Retrieved 15 March 2019 from http://www.gov.ph/constitutions/the-1987-constitution-of-the-republic-of-thephilippines/the-1987-constitution-of-the-republic-of-the-philippines-article-ii/

Tope L. \& Nonan-Mercado R. (2002). Philippines (Cultures of the World). New York, NY: Cavendish Square Publishing.

UNESCO (2005). International Conference on Globalization and Intangible Cultural Heritage. L.Wong (ed.) Belgium: J. Verhoeven.

Walter, T. (2008). The sociology of death. Sociology compass, 2(1), 317-336.

Wardekker, W. L., \& Miedema, S. (2001). Identity, Cultural Change, and Religious Education. British Journal of Religious Education, 23(2), 76-87. doi:10.1080/0141620010230202

Wiggins, G. P., \& McTighe, J. (2005). Understanding by design. Alexandria, VA: Association for Supervision and Curriculum Development. 